\title{
PRACTICAL METHOD OF FLEXURAL STRENGTH CALCULATION OF REINFORCED AND PRESTRESSED CONCRETE MEMBERS
}

\author{
Vello Otsmaa ${ }^{1}$, Tiit Pedak $^{2}$ \\ Dept of Structural Design, Tallinn University of Technology, Ehitajate tee 5, 19086 Tallinn, Estonia \\ E-mails: ${ }^{1}$ vello.otsmaa@ttu.ee, ${ }^{2}$ tiitpedak@hot.ee
}

Received 29 June 2007; accepted 17 Dec 2007

\begin{abstract}
In this paper the flexural strength analysis of reinforced and prestressed concrete members with symmetrical cross-sections loaded in the plane of symmetry is performed. A new practical method for determining the height of the compression zone is proposed. The method is valid for normal and high-strength concretes and for different distributions of bars along the section. It is based on the assumptions, simplifications and material properties of Eurocode 2. Design equations have been developed for the rectangular stress distribution in the concrete compression zone and for the steel stressstrain diagrams with a horizontal and inclined top branch. A numerical example is presented to show the method usage.
\end{abstract}

Keywords: calculation method, flexural strength, reinforced and prestressed concrete, symmetrical cross-section, plane of bending, compression zone height.

\section{Introduction}

The flexural strength analysis of reinforced and prestressed concrete members is based on conditions of static equilibrium, strain compatibility and material properties. The unknown members in the corresponding equations can be expressed in simple or complicated way depending on the applied stress-strain curves for materials.

This paper observes symmetrical cross-sections loaded in the plane of symmetry. A detailed section analysis based on complete stress-strain relations can be carried out. In this case, the compression force in the concrete is calculated by the integration of stresses over the concrete area and the force equilibrium at the section is achieved by an iterative procedure. The integration methods and the iterative procedure are laborious to perform manually, therefore computers are used [1-3]. In spite of general use of computers the practical methods of calculation have not lost their importance in certain cases. These methods enable simpler calculations, control of computer results and overview of the performed computations. The practical methods are either graphical or analytical. The graphical interaction diagrams are usually available for simple sections (rectangle, circle), normal-strength concrete and more commonly used steel locations [4-6]. For high-strength concrete and uncommon arrangement of steel these diagrams cannot be applied. In the absence of specific interaction diagram, an alternative to construct the diagram is to use the analytical expressions. The complexity of expressions depends on the used idealisations for stress-strain curves and the geometry of section. It is very usual to apply the rectangular stress block assumption for concrete and the elastic-perfectly plastic approximation for reinforcing and prestressing steel. More commonly used cross-sections, for which at these idealisations the analytical expressions exist, are rectangular and flanged sections with a distribution of reinforcement along the sides parallel to the axis of bending. As the prestressing steel does not exhibit a welldefined yield plateau than in Eurocode 2 [7], the design is allowed to base on the actual curve, if this is known or in some other codes the analytical expressions for the shape of actual curve are accepted. In these cases, the corresponding flexural strength analysis leads to an iterative procedure [8], which for practical calculations can be tedious. Several other approximate procedures for the prestressing steel in the flexural strength analysis have been presented $[9,10]$.

The objective of the current paper is to present a practical method of calculation by which a symmetrical cross- 
section of beams and columns with arbitrary arrangement of bars can be analysed. The method can be applied to both normal and high-strength concretes and various stress-strain relationships for reinforcing and prestressing steel according to Eurocode 2.

\section{Strain distribution in a cross-section}

The strain distribution of cross-section will be found by using "plane sections remain plane" assumption and in Standard EN1992-1-1:2004 [7] given stress-strain relationships for materials. Two strains are needed to determine the strain distribution for members carrying load in the plane of symmetry. One of them can be the strain at neutral axis and the other one of the following limiting strains (Fig 1):

- reinforcing or prestressing steel tension strain limit $\varepsilon_{u d}$ (point A);

- concrete compression strain limit $\varepsilon_{c u 2}$ or $\varepsilon_{c u 3}$ depending on the stress-strain diagram used (point B);

- concrete pure compression strain limit $\varepsilon_{c 2}$ or $\varepsilon_{c 3}$ (point C).

For cases where there is a compression over all the section of limiting strain $\varepsilon_{c 2}$ or $\varepsilon_{c 3}$ occurs in the fibre located at $x_{c}$ from the extreme compression edge:

$$
x_{c}=\left(1-\frac{\varepsilon_{c 2}}{\varepsilon_{c u 2}}\right) h \text { or } x_{c}=\left(1-\frac{\varepsilon_{c 3}}{\varepsilon_{c u 3}}\right) h .
$$

When the rotations in bending are small, the strains are proportional to the angle change over a unit length of beam $\psi$ and vary linearly with distance $y$ from the neutral axis:

$$
\varepsilon=\psi y
$$

From the geometry in the figure (using limiting strains $\varepsilon_{c 2}$ and $\left.\varepsilon_{c u 2}\right)$ :

$$
\psi= \begin{cases}\frac{\varepsilon_{c u 2}}{x}, & \text { if } x \leq h, \\ \frac{\varepsilon_{c 2}}{x-x_{c}}, & \text { if } x>h, \\ \frac{\varepsilon_{u d}}{d-x}, & \text { if } x \leq \frac{\varepsilon_{c u 2}}{\varepsilon_{u d}+\varepsilon_{c u 2}} d,\end{cases}
$$

where $x$ is the height of compression zone, $d$ - the distance from the extreme compression fibre to the centroid of the tension steel and $\varepsilon_{c u 2}, \varepsilon_{c 2}, \varepsilon_{u d}$ are the abovementioned strains. The strains $\varepsilon_{c u 2}, \varepsilon_{c 2}, \varepsilon_{u d}$ have been taken as positive.

The Eq (2) can be modified for calculating steel strains: the strain in the reinforcing steel $\varepsilon_{s}$ :

$\varepsilon_{s}= \begin{cases}\psi\left(d_{s}-x\right), & \text { if strains in steel are not limited } \\ \psi\left(d_{s}-x\right) \leq \varepsilon_{u d}, & \text { if strains in steel are limited }\end{cases}$

the strain in the prestressing steel $\varepsilon_{p}$ with the prestrain $\varepsilon_{p m}$ :

$$
\varepsilon_{p}= \begin{cases}\varepsilon_{p m}+\psi\left(d_{p}-x\right), & \text { if strains in steel } \\ \varepsilon_{p m}+\psi\left(d_{p}-x\right) \leq \varepsilon_{u d}, & \text { are not limited } \\ & \text { are strains in steel }\end{cases}
$$

where $d_{s}$ and $d_{p}$ are the distances from the extreme compression fibre to the centroids of the reinforcing and prestressing steels respectively.

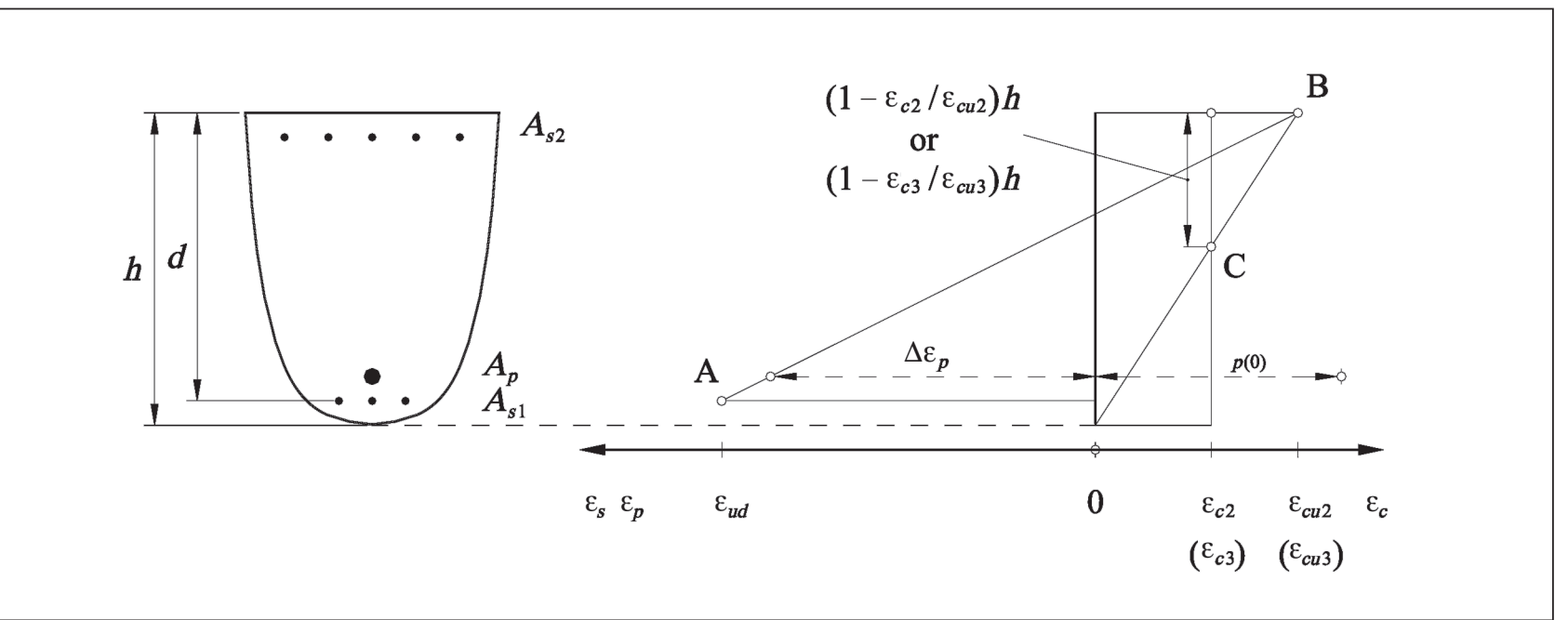

Fig 1. Possible strain distributions in the ultimate limit state [7] 


\section{Stress distribution of cross-section}

For the concrete in compression a rectangular stress distribution is used. For the steel the stress-strain diagram with a horizontal or an inclined top branch is used [7]. To these diagrams (Fig 2) are added formulars to find stresses in region of strain hardening (inclined top branch). Taking into account Eqs (4) and (5), the stresses become:

diagram a, the stress in the reinforcing steel $\sigma_{s}$ :

$$
\sigma_{s}=\left\{\begin{array}{cc}
\psi\left(d_{s}-x\right) E_{s} & , \text { if }\left|\varepsilon_{s}\right| \leq\left|\varepsilon_{y d}\right|, \text { lower branch } \\
f_{y d} & \text { if }\left|\varepsilon_{s}\right| \geq\left|\varepsilon_{y d}\right|, \text { horizontal } \\
\text { top branch } \\
f_{y d}\left(1-\frac{\bar{E}_{s}}{E_{s}}\right)+\psi\left(d_{s}-x\right) \bar{E}_{s}, & \text { if }\left|\varepsilon_{y d}\right| \leq\left|\varepsilon_{s}\right| \leq\left|\varepsilon_{u d}\right| \\
& \text { inclined top branch; }
\end{array}\right.
$$

diagram $\mathrm{b}$, the stress in the prestressing steel $\sigma_{p}$ with the prestress $\sigma_{p m}$ :

$$
\sigma_{p}= \begin{cases}\sigma_{p m}+\psi\left(d_{p}-x\right) E_{p}, & \text { if } \varepsilon_{p} \leq \varepsilon_{f p d}, \\ & \text { lower branch } \\ f_{p d}, & \text { if } \varepsilon_{p} \geq \varepsilon_{f p d}, \\ & \text { horizontal top branch } \\ f_{p d}-\left(f_{p d}-\sigma_{p m}\right) \frac{\bar{E}_{p}}{E_{p}}+\psi\left(d_{p}-x\right) \bar{E}_{p}, \\ \text { if } \varepsilon_{f p d} \leq \varepsilon_{p} \leq \varepsilon_{u d},\end{cases}
$$

where the slopes of top branch of diagram for reinforcing and prestressing steel are $\bar{E}_{s}=\frac{f_{y d}(k-1)}{\varepsilon_{u k}-\varepsilon_{y d}} \quad$ and
$\bar{E}_{p}=\frac{f_{p d}(k-1)}{\varepsilon_{u k}-\varepsilon_{f p d}}$ respectively, $E_{s}$ and $E_{p}$ are the moduli of elasticity for reinforcing and prestressing steel. For the slope equations the following characteristic values are used: $f_{y d}$ and $f_{p d}$ - design strength of reinforcing and prestressing steel,

$\varepsilon_{y d}$ and $\varepsilon_{f p d}$ - strains according to the design strength of reinforcing and prestressing steel,

$\varepsilon_{u k}$ - characteristic strain of steel at maximum force.

\section{Height of compression zone}

\subsection{Steel stress-strain diagram with horizontal top branch}

We consider a symmetrical cross-section reinforced by a number of layers of steel and subjected to a design bending moment $M_{E d}$ and a design axial force $N_{E d}$ (Fig 3).

Summing axial forces gives the following equation of equilibrium:

$$
\eta f_{c d} A_{c}-\sum_{i=1}^{n} \sigma_{s i} A_{s i}-\sum_{j=1}^{m} \sigma_{p j} A_{p j}-N_{E d}=0
$$

where $f_{c d}$ is the design compressive strength of concrete, $\eta-\mathrm{a}$ factor depending on the strength class for concrete, $A_{c}$ - the effective area of concrete in compression, $A_{s i}$ and $A_{p j}$ - the areas of reinforcing and prestressing steel respectively. Summations in $\mathrm{Eq}(8)$ are to be performed from $i=1$ to $n$ and $j=1$ to $m$, where $n$ and $m$ are the numbers of reinforcing and prestressing steel layers respectively. The area $A_{c}$ can be written as the sum of two parts:

$$
A_{c}= \begin{cases}b^{*} \dot{\mathrm{e}} x+\Delta A_{c}, & \text { if } \dot{\mathrm{e}} x<h, \\ b h+\Delta A_{c}, & \text { if } \dot{\mathrm{e}} x \geq h,\end{cases}
$$

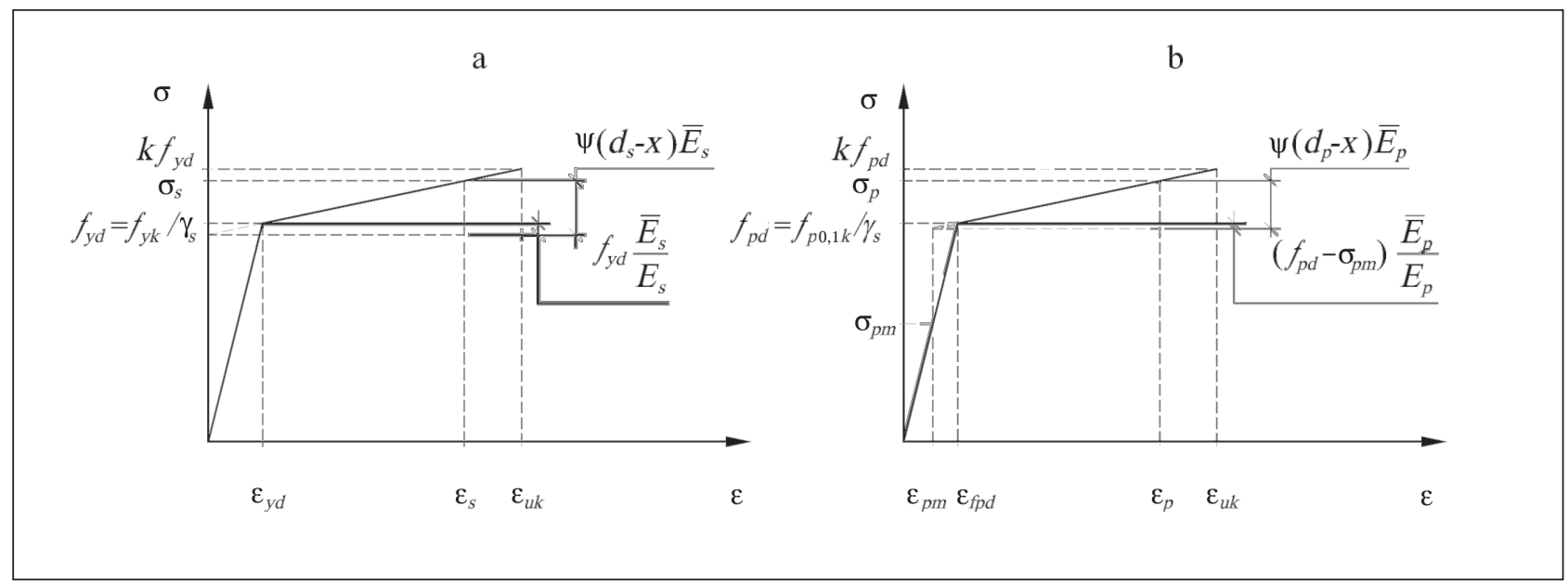

Fig 2. Design stress-strain diagrams for reinforcing steel (a) and prestressing steel (b) 


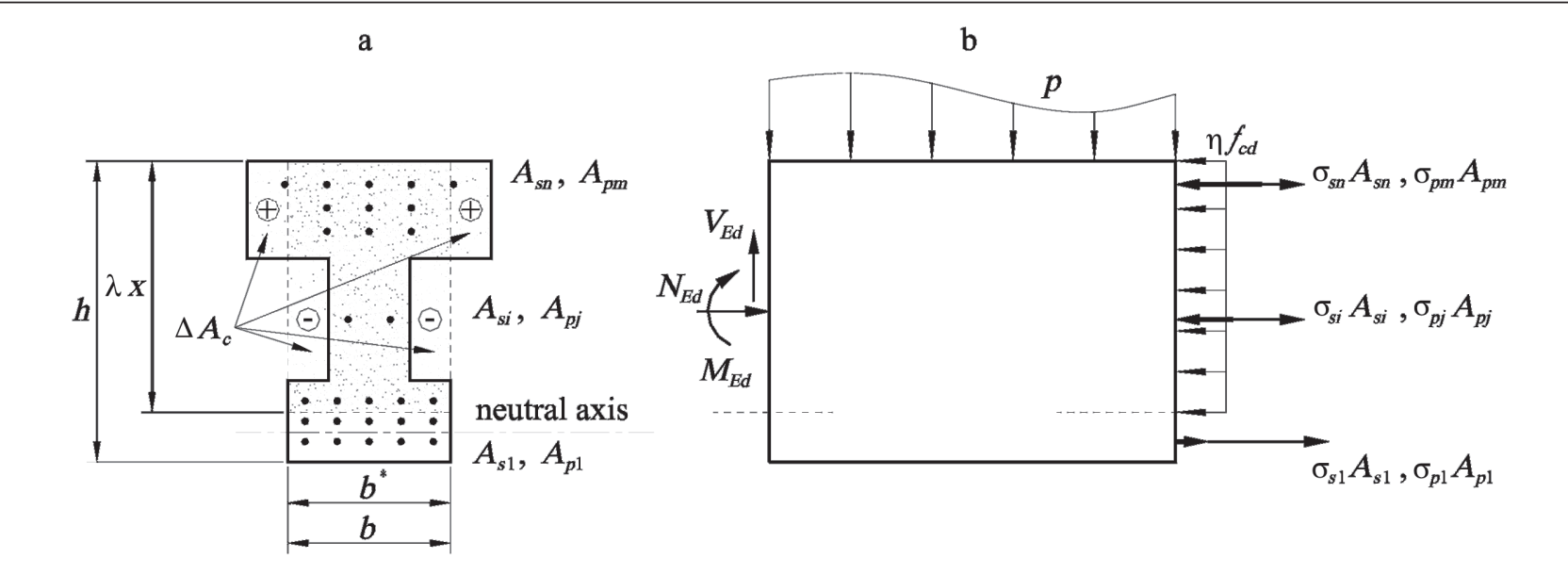

Fig 3. Cross-section (a); stresses and forces (b)

where $b^{*}$ is the section width at the effective height of compression zone $\dot{\mathrm{e} x}$, $\dot{\mathrm{e}}$ is a factor depending on the strength class for concrete. The area $\Delta A_{c}$ is obtained by summing the "positive areas" and the "negative areas" (Fig 3 ) and can have various values depending on the shape of cross-section and the position of neutral axis.

Flexural strength calculations in the case $\dot{\mathrm{e}} x \geq h$ can usually be carried out without determining the height of compression zone. Here we consider the case $\dot{\mathrm{e}} x<h$.

Substituting Eq (6) and (7) into Eq (8) we get:

$$
\begin{aligned}
& \eta f_{c d} b^{*} \dot{\mathrm{e}} x+\eta f_{c d} \Delta A_{c}-\sum_{i=1}^{n} \psi\left(d_{s i}-x\right) E_{s} A_{s i}-\sum_{i=1}^{n} f_{y d} A_{s i}- \\
& \sum_{j=1}^{m}\left[\sigma_{p j m}+\psi\left(d_{p j}-x\right) E_{p}\right] A_{p j}-\sum_{j=1}^{m} f_{p d} A_{p j}-N_{E d}=0,(10)
\end{aligned}
$$

where members containing steel stresses define the sum of forces in steel layers:

$$
\begin{gathered}
\sum_{i=1}^{n} \psi\left(d_{s i}-x\right) E_{s} A_{s i}, \text { if }\left|\sigma_{s}\right|<\left|f_{y d}\right|, \\
\sum_{i=1}^{n} f_{y d} A_{s i}, \text { if }\left|\sigma_{s}\right|=\left|f_{y d}\right|, \\
\sum_{j=1}^{m}\left[\sigma_{p j m}+\psi\left(d_{p j}-x\right) E_{p}\right] A_{p j}, \text { if } \sigma_{p}<f_{p d}, \\
\sum_{j=1}^{m} f_{p d} A_{p j}, \text { if } \sigma_{p}=f_{p d} .
\end{gathered}
$$

Next we multiply Eq (10) with distances between neutral axis and fibres with strains $\varepsilon_{c u 2}, \varepsilon_{c 2}$ and consider $\mathrm{Eq}(3)$. To represent the result by one equation we use Macaulay function:

$$
F_{0}(x)=\langle x-a\rangle^{0}=\left\{\begin{array}{l}
0, \text { if } x \leq a \\
1, \text { if } x>a .
\end{array}\right.
$$

Arranging the members in the equilibrium equation according to the power of height $x$, we get:

$$
\begin{gathered}
\eta f_{c d} b^{*} \dot{\mathrm{e}} x^{2}-\left[-\sum_{i=1}^{n} \sigma_{s c, u} A_{s i}+\sum_{i=1}^{n} f_{y d} A_{s i}+\right. \\
\sum_{j=1}^{m}\left(\sigma_{p j m}-\sigma_{p c, u}\right) A_{p j}+\sum_{j=1}^{m} f_{p d} A_{p j}\langle h-x\rangle^{0}- \\
\left.\eta f_{c d} \Delta A_{c}+N_{E d}+\eta f_{c d} b^{*} \dot{\mathrm{e}} x_{c}\langle x-h\rangle^{0}\right] x- \\
{\left[\sum_{i=1}^{n} \sigma_{s c, u} A_{s i} d_{s i}-\sum_{i=1}^{n} f_{y d} A_{s i} x_{c}\langle x-h\rangle^{0}+\right.} \\
\sum_{j=1}^{m}\left(\sigma_{p c, u} d_{p j}-\sigma_{p j m} x_{c}\langle x-h\rangle^{0}\right) A_{p j}+ \\
\left.\left(\eta f_{c d} \Delta A_{c}-N_{E d}\right) x_{c}\langle x-h\rangle^{0}\right]=0,
\end{gathered}
$$

where the reinforcing and prestressing steel conditional stresses $\sigma_{s c, u}$ and $\sigma_{p c, u}$ corresponding to the limiting compressive strains in concrete $\varepsilon_{c u 2}$ and $\varepsilon_{c 2}$ are:

$$
\sigma_{s c, u}=\left\{\begin{array}{l}
\varepsilon_{c u 2} E_{s}, \text { if } x \leq h, \\
\varepsilon_{c 2} E_{s}, \text { if } x>h,
\end{array} \sigma_{p c, u}=\left\{\begin{array}{l}
\varepsilon_{c u 2} E_{p}, \text { if } x \leq h, \\
\varepsilon_{c 2} E_{p}, \text { if } x>h .
\end{array}\right.\right.
$$

Eq (12) is a quadratic equation of the form:

$$
A x^{2}-B x-C=0,
$$

and the height of compression zone is given by the positive root:

$$
x=\frac{B+\sqrt{B^{2}+4 A C}}{2 A},
$$


where the coefficients $A, B$ and $C$ are:

$$
\begin{gathered}
A=\eta f_{c d} b^{*} \lambda \\
B=-\sum_{i=1}^{n} \sigma_{s c, u} A_{s i}+\sum_{i=1}^{n} f_{y d} A_{s i}+ \\
\sum_{j=1}^{m}\left(\sigma_{p j m}-\sigma_{p c, u}\right) A_{p j}+\sum_{j=1}^{m} f_{p d} A_{p j}\langle h-x\rangle^{0}- \\
\eta f_{c d} \Delta A_{c}+N_{E d}+\eta f_{c d} b^{*} \lambda x_{c}\langle x-h\rangle^{0} \\
C=\sum_{i=1}^{n} \sigma_{s c, u} A_{s i} d_{s i}-\sum_{i=1}^{n} f_{y d} A_{s i} x_{c}\langle x-h\rangle^{0}+\sum_{j=1}^{m}\left(\sigma_{p c, u} d_{p j}-\right. \\
\left.\sigma_{p j m} x_{c}\langle x-h\rangle^{0}\right) A_{p j}+\left(\eta f_{c d} \Delta A_{c}-N_{E d}\right) x_{c}\langle x-h\rangle^{0}
\end{gathered}
$$

The members

$\sum_{i=1}^{n} \sigma_{s c, u} A_{s i}, \quad \sum_{i=1}^{n} \sigma_{s c, u} A_{s i} d_{s i}, \quad \sum_{j=1}^{m}\left(\sigma_{p j m}-\sigma_{p c, u}\right) A_{p j}$, $\sum_{j=1}^{m}\left(\sigma_{p c, u} d_{p j}-\sigma_{p j m} x_{c}\langle x-h\rangle^{0}\right) A_{p j}$ will be found according to steel layers, where the stresses are less than the yield stress and the members $\sum_{i=1}^{n} f_{y d} A_{s i}, \sum_{i=1}^{n} f_{y d} A_{s i} x_{c}\langle x-h\rangle^{0}$, $\sum_{j=1}^{m} f_{p d} A_{p j}(h-x)^{0}$ according to steel layers, where the stresses are equal to the yield stress.

If the steel stresses are equal to the yield stress, then Eq (8) gives a linear equation in $x$ :

$$
\eta f_{c d} b^{*} \dot{\mathrm{e}} x+\eta f_{c d} \Delta A_{c}-\sum_{i=1}^{n} f_{y d} A_{s i}-\sum_{j=1}^{m} f_{p d} A_{p j}-N_{E d}=0
$$

\subsection{Steel stress-strain diagram with an inclined top branch}

Using the stress-strain diagrams with a horizontal and an inclined top branch for compression and tension zone respectively, Eq (8) becomes:

$$
\begin{gathered}
\eta f_{c d} b^{*} \dot{\mathrm{e}} x+\eta f_{c d} \Delta A_{c}-\sum_{i=1}^{n} \psi\left(d_{s i}-x\right) E_{s} A_{s i}- \\
\sum_{i=1}^{n} f_{y d} A_{s i}-\sum_{i=1}^{n}\left[f_{y d}\left(1-\frac{\bar{E}_{s}}{E_{s}}\right)+\psi\left(d_{s i}-x\right) \bar{E}_{s}\right] A_{s i}- \\
\sum_{j=1}^{m}\left[\sigma_{p j m}+\psi\left(d_{p j}-x\right) E_{p}\right] A_{p j}- \\
\sum_{j=1}^{m}\left[f_{p d}-\left(f_{p d}-\sigma_{p j m}\right) \frac{\bar{E}_{p}}{E_{p}}+\psi\left(d_{p j}-x\right) \bar{E}_{p}\right] A_{p j}-
\end{gathered}
$$

$$
N_{E d}=0,
$$

where the members containing steel stresses express the sum of forces in steel layers:

$$
\begin{gathered}
\sum_{i=1}^{n} \psi\left(d_{s i}-x\right) E_{s} A_{s i}, \text { if } \sigma_{s}<f_{y d}, \\
\sum_{i=1}^{n}\left[f_{y d}\left(1-\frac{\bar{E}_{s}}{E_{s}}\right)+\psi\left(d_{s i}-x\right) \bar{E}_{s}\right] A_{s i}, \text { if } \\
f_{y d} \leq \sigma_{s} \leq k f_{y d}, \\
\sum_{j=1}^{m}\left[\sigma_{p j m}+\psi\left(d_{p j}-x\right) E_{p}\right] A_{p j}, \text { if } \sigma_{p}<f_{p d}, \\
\sum_{j=1}^{m}\left[f_{p d}-\left(f_{p d}-\sigma_{p j m}\right) \frac{\bar{E}_{p}}{E_{p}}+\psi\left(d_{p j}-x\right) \bar{E}_{p}\right] A_{p j}, \\
\text { if } f_{p d} \leq \sigma_{p} \leq k f_{p d} .
\end{gathered}
$$

Let us see the case, where the strain diagram in Fig 1 goes through the point $\mathrm{B}$, then $\psi=\varepsilon_{c u 2} / x$ and $\frac{\varepsilon_{c u 2}}{\varepsilon_{u d}+\varepsilon_{c u 2}} d \leq x \leq h$. Using the represented train of thought, we obtain the coefficients of quadratic equation as follows:

$$
\begin{gathered}
A=\eta f_{c d} b^{*} \dot{\mathrm{e}} \\
B=-\sum_{i=1}^{n} \sigma_{s c, u} A_{s i}+\sum_{i=1}^{n} f_{y d} A_{s i}+ \\
\sum_{i=1}^{n}\left[f_{y d}\left(1-\frac{\bar{E}_{s}}{E_{s}}\right)-\bar{\sigma}_{s c, u}\right] A_{s i}+\sum_{j=1}^{m}\left(\sigma_{p j m}-\sigma_{p c, u}\right) A_{p j}+ \\
\sum_{j=1}^{m}\left[f_{p d}-\left(f_{p d}-\sigma_{p j m}\right) \frac{\bar{E}_{p}}{E_{p}}-\bar{\sigma}_{p c, u}\right] A_{p j}- \\
\eta f_{c d} \Delta A_{c}+N_{E d} \\
C=\sum_{i=1}^{n} \sigma_{s c, u} A_{s i} d_{s i}+\sum_{i=1}^{n} \bar{\sigma}_{s c, u} A_{s i} d_{s i}+ \\
\sum_{j=1}^{m} \sigma_{p c, u} A_{p j} d_{p j}+\sum_{j=1}^{m} \bar{\sigma}_{p c, u} A_{p j} d_{p j}
\end{gathered}
$$

where

$$
\bar{\sigma}_{s c, u}=\left\{\begin{array}{l}
\varepsilon_{c u 2} \bar{E}_{s}, \text { if } x \leq h \\
\varepsilon_{c 2} \bar{E}_{s}, \text { if } x>h,
\end{array} \bar{\sigma}_{p c, u}=\left\{\begin{array}{l}
\varepsilon_{c u 2} \bar{E}_{p}, \text { if } x \leq h \\
\varepsilon_{c 2} \bar{E}_{p}, \text { if } x>h .
\end{array}\right.\right.
$$


Coefficients of equation $A x^{2}-B x-C=0$

\begin{tabular}{|c|c|c|c|c|c|c|}
\hline \multirow{2}{*}{ 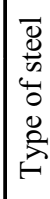 } & \multirow[b]{2}{*}{$\begin{array}{l}\text { Steel stress in } \\
\text { layer }\end{array}$} & \multirow[b]{2}{*}{$A$} & \multicolumn{2}{|l|}{$B$} & \multicolumn{2}{|c|}{ C } \\
\hline & & & \begin{tabular}{c|} 
Part 1: \\
Dependence on steel stresses
\end{tabular} & $\begin{array}{c}\text { Part 2: } \\
\text { Dependence on } \\
\text { concrete strength and } \\
\text { axial force } \\
\end{array}$ & $\begin{array}{c}\text { Part 1: } \\
\text { Dependence on steel } \\
\text { stresses }\end{array}$ & $\begin{array}{c}\text { Part 2: } \\
\text { Dependence on } \\
\text { concrete strength and } \\
\text { axial force }\end{array}$ \\
\hline 1 & 2 & 3 & 4 & 5 & 6 & 7 \\
\hline \multirow{3}{*}{ 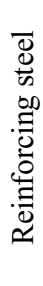 } & $\left|\sigma_{\mathrm{s}}\right|<\left|f_{y d}\right|$ & \multirow{6}{*}{$\eta f_{c d} b^{*} \lambda$} & $-\sigma_{s c, u} A_{s}$ & \multirow{6}{*}{$\begin{array}{c}-\eta f_{c d} \Delta A_{c}+N_{E d}+ \\
\eta f_{c d} b^{*} \dot{\mathrm{e}} x_{c}\langle x-h\rangle^{0}\end{array}$} & $\sigma_{s c, u} A_{s} d_{s}$ & \multirow{6}{*}{$\begin{array}{c}\left(\eta f_{c d} \Delta A_{c}-N_{E d}\right) \\
\cdot x_{c}\langle x-h\rangle^{0}\end{array}$} \\
\hline & $\left|\sigma_{s}\right|=\left|f_{y d}\right|$ & & $f_{y d} A_{s}$ & & $-f_{y d} A_{s} x_{c}\langle x-h\rangle^{0}$ & \\
\hline & $f_{y d} \leq \sigma_{s} \leq k f_{y d}$ & & {$\left[f_{y d}\left(1-\frac{\bar{E}_{s}}{E_{s}}\right)-\bar{\sigma}_{s c, u}\right] A_{s}$} & & $\bar{\sigma}_{s c, u} A_{s} d_{s}$ & \\
\hline \multirow{3}{*}{ 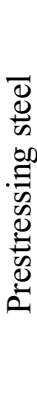 } & $\sigma_{p}<f_{p d}$ & & $\left(\sigma_{p m}-\sigma_{p c, u}\right) A_{p}$ & & $\begin{array}{c}\left(\sigma_{p c, u} d_{p}-\right. \\
\left.\sigma_{p m} x_{c}\langle x-h\rangle^{0}\right) A_{p}\end{array}$ & \\
\hline & $\sigma_{p}=f_{p d}$ & & $f_{p d} A_{p}\langle h-x\rangle^{0}$ & & - & \\
\hline & $f_{p d} \leq \sigma_{p} \leq k f_{p d}$ & & {$\left[\begin{array}{c}{\left[f_{p d}-\left(f_{p d}-\sigma_{p m}\right) \frac{\bar{E}_{p}}{E_{p}}-\right.} \\
\left.\bar{\sigma}_{p c, u}\right] A_{p}\end{array}\right.$} & & $\bar{\sigma}_{p c, u} A_{p} d_{p}$ & \\
\hline
\end{tabular}

1) reinforcing steel in tension zone

2) prestressing steel in tension zone (14)

The height of compression zone is obtained from Eq

The determination of coefficients $A, B$ and $C$ can also be carried out for both stress-strain diagrams by the Table given below. Coefficients $B$ and $C$ consist of 2 parts:

- part 1 represents the dependence on steel stresses and is calculable by summing up the members for each steel layer according to their stresses;

- part 2 is calculable depending on concrete strength and axial force.

The table can also be used to determine the height of compression zone when $\dot{\mathrm{e} x} \geq h$. In that case coefficient $A=0$ and contents of columns 5 and 7 will be turned into $\left(-\eta f_{c d} A_{c}+N_{E d}\right)$ and $\left(\eta f_{c d} A_{c}-N_{E d}\right) x_{c}$ respectively.

At the beginning of calculations the position of neutral axis shall be assumed. The following calculations will show, whether the assumption was right, or the calculations shall be repeated with another position of neutral axis. For control there are steel stresses (Eq (6), (7)), what cannot exceed the tensile strength and the stresses determined by strain distribution of section.

There are the following possibilities to find the coefficients of Eq (13) for the assumed position of neutral axis:
- to compare the steel stresses with the yield strength (or to compare respective strains);

- to compare the relative height of compression zone with the respective relative height to the yield strength.

\section{Flexural strength calculation}

Once the value of height of compression zone is known, the stresses in each layer of steel can be computed. In the reinforcing steel:

$$
\sigma_{s}= \begin{cases}\sigma_{s c, u}\left(\frac{d_{s}}{x}-1\right), & \text { if }\left|\sigma_{s}\right| \leq\left|f_{y d}\right| \text { and } x \leq h, \\ \sigma_{s c, u}\left(\frac{d_{s}-x}{x-x_{c}}\right), & \text { if }\left|\sigma_{s}\right| \leq\left|f_{y d}\right| \text { and } x>h, \\ f_{y d}, & \text { if }\left|\sigma_{s}\right| \geq\left|f_{y d}\right|, \\ f_{y d}\left(1-\frac{\bar{E}_{s}}{E_{s}}\right)+\bar{\sigma}_{s c, u}\left(\frac{d_{s}}{x}-1\right) \text { if } f_{y d} \leq \sigma_{s} \leq k f_{y d} ;\end{cases}
$$


in the prestressing steel:

$$
\sigma_{p}=\left\{\begin{array}{cc}
\sigma_{p m}+\sigma_{p c, u}\left(\frac{d_{p}}{x}-1\right), & \text { if } \sigma_{p} \leq f_{p d} \text { and } x \leq h, \\
\sigma_{p m}+\sigma_{p c, u}\left(\frac{d_{p}-x}{x-x_{c}}\right), & \text { if } \sigma_{p} \leq f_{p d} \text { and } x>h, \\
f_{p d}, & \text { if } \sigma_{p} \geq f_{p d}, \\
f_{p d}-\left(f_{p d}-\sigma_{p m}\right) \frac{\bar{E}_{p}}{E_{p}}+\bar{\sigma}_{p c, u}\left(\frac{d p}{x}-1\right) \\
\text { if } f_{p d} \leq \sigma_{p} \leq k f_{p d} .
\end{array}\right.
$$

Finally the ultimate moment resistance of the section $M_{\text {Rd }}$ can be found. For instance, taking moments about the mid-height of the section we obtain:

$$
\begin{gathered}
M_{R d}=\eta f_{c d} b^{*} \dot{\mathrm{e}} x(0,5 h-0,5 \mathrm{e} x)+\eta f_{c d} \Delta S_{c}- \\
\sum_{i=1}^{n} \sigma_{s i} A_{s i}\left(0,5 h-d_{s i}\right)-\sum_{j=1}^{m} \sigma_{p j} A_{p j}\left(0,5 h-d_{p j}\right)
\end{gathered}
$$

where $\Delta S_{c}$ is the first moment of the area $\Delta A_{c}$ about the mid-height of the section.

\section{Example}

The ultimate moment resistance of the section shown in Fig 4 is calculated by the proposed method.

Given: Concrete C35/45, $f_{c d}=19,83 \mathrm{~N} / \mathrm{mm}^{2}$, $\varepsilon_{c u 2}=0,0035, \eta=1, \dot{\mathrm{e}}=0,8$.

Prestressing steel St1570/1770, $f_{p k}=1770 \mathrm{~N} / \mathrm{mm}^{2}$, $f_{p k} / \gamma_{s}=1770 / 1,15=1539 \mathrm{~N} / \mathrm{mm}^{2}$, $f_{p 0,1 k}=1500 \mathrm{~N} / \mathrm{mm}^{2}$,

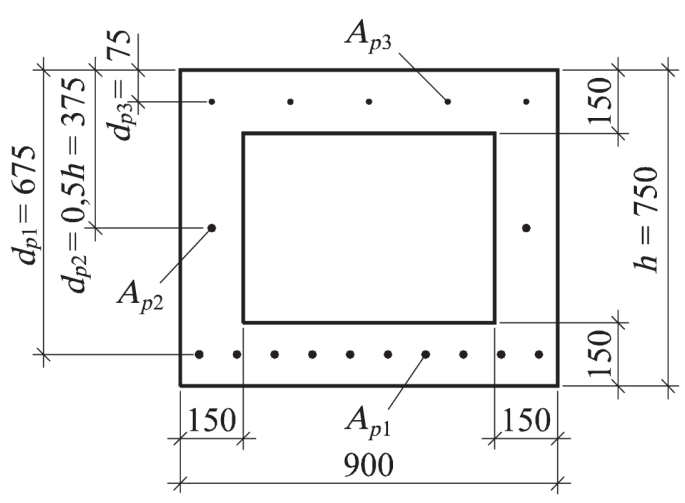

Fig 4. Boxed section $f_{p d}=f_{p 0,1 k} / \gamma_{s}=1500 / 1,15=1304 \mathrm{~N} / \mathrm{mm}^{2}$,

$k=f_{p k} / f_{p 0,1 k}=1770 / 1500=1,180, \quad \varepsilon_{u k}=0,035$,

$E_{p}=195000 \mathrm{~N} / \mathrm{mm}^{2}$,

$\varepsilon_{f p d}=f_{p d} / E_{p}=1304 / 195000=0,006687$,

$\bar{E}_{p}=\frac{f_{p d}(k-1)}{\varepsilon_{u k}-\varepsilon_{f p d}}=\frac{1304(1,180-1)}{0,035-0,006687}=8290 \mathrm{~N} / \mathrm{mm}^{2}$,

$\sigma_{p c, u}=\varepsilon_{c u 2} E_{p}=0,0035 \cdot 195000=682,5 \mathrm{~N} / \mathrm{mm}^{2}$,

$\bar{\sigma}_{p c, u}=\varepsilon_{c u 2} \bar{E}_{p}=0,0035 \cdot 8290=29,01 \mathrm{~N} / \mathrm{mm}^{2}$,

$A_{p 1}=2000 \mathrm{~mm}^{2}(10 \varnothing 18,0)$,

$A_{p 2}=400 \mathrm{~mm}^{2}(2 \varnothing 18,0), \quad A_{p 3}=260 \mathrm{~mm}^{2}(5 \varnothing 9,3)$,

$\sigma_{p 1 m}=\sigma_{p 2 m}=\sigma_{p 3 m}=1000 \mathrm{~N} / \mathrm{mm}^{2}$.

1) The calculations based on the stress-strain diagram with horizontal top branch.

Assuming that the steel in the layer 1 of strands yields and the compression zone extends into the web the coefficients of Eq (13) are:

$$
\begin{gathered}
A=\eta f_{c d} b^{*} \dot{\mathrm{e}}=1 \cdot 19,83 \cdot 300 \cdot 0,8=4759 \mathrm{~N} / \mathrm{mm}, \\
B=f_{p d} A_{p 1}+\sum_{j=2}^{3}\left(\sigma_{p j m}-\sigma_{p c, u}\right) A_{p j}-\eta f_{c d} \Delta A_{c}= \\
1304 \cdot 2000+(1000-682,5) 400+ \\
(1000-682,5) 260-1 \cdot 19,83 \cdot 90000=1033 \cdot 10^{3} \mathrm{~N}, \\
C=\sum_{j=2}^{3} \sigma_{p c, u} A_{p j} d_{p j}=682,5 \cdot 400 \cdot 375+ \\
682,5 \cdot 260 \cdot 75=115,7 \cdot 10^{6} \mathrm{Nmm},
\end{gathered}
$$

where $\Delta A_{c}=600 \cdot 150=90000 \mathrm{~mm}^{2}$.

The height of compression zone:

$$
\begin{gathered}
x=\frac{B+\sqrt{B^{2}+4 A C}}{2 A}= \\
\frac{1033 \cdot 10^{3}+\sqrt{\left(1033 \cdot 10^{3}\right)^{2}+4 \cdot 4759 \cdot 115,7 \cdot 10^{6}}}{2 \cdot 4759}= \\
298 \mathrm{~mm} .
\end{gathered}
$$

The steel stresses:

$\sigma_{p 1}=\sigma_{p 1 m}+\sigma_{p c, u}\left(\frac{d_{p 1}}{x}-1\right)=1000+682,5\left(\frac{675}{298}-1\right)=$

$1861 \mathrm{~N} / \mathrm{mm}^{2}>f_{p d}=1304 \mathrm{~N} / \mathrm{mm}^{2}$, 


$$
\begin{gathered}
\sigma_{p 2}=\sigma_{p 2 m}+\sigma_{p c, u}\left(\frac{d_{p 2}}{x}-1\right)=1000+682,5\left(\frac{375}{298}-1\right)= \\
1175 \mathrm{~N} / \mathrm{mm}^{2}<f_{p d}=1304 \mathrm{~N} / \mathrm{mm}^{2} \\
\sigma_{p 3}=\sigma_{p 3 m}+\sigma_{p c, u}\left(\frac{d_{p 3}}{x}-1\right)=1000+682,5\left(\frac{75}{298}-1\right)=
\end{gathered}
$$

$489,0 \mathrm{~N} / \mathrm{mm}^{2}$

thus the steel in the layer 1 yields $\sigma_{p 1}=f_{p d}$. Taking moments about the mid-height of the section, we get the ultimate moment resistance of section:

$$
\begin{gathered}
M_{R d}=\eta f_{c d} b^{*} \dot{\mathrm{e}} x(0,5 h-0,5 \dot{\mathrm{e}} x)+\eta f_{c d} \Delta S_{c}- \\
\sum_{j=1}^{3} \sigma_{p j} A_{p j}\left(0,5 h-d_{p j}\right)=
\end{gathered}
$$

$1 \cdot 19,83 \cdot 300 \cdot 0,8 \cdot 298(375-0,5 \cdot 0,8 \cdot 298)+$

$1 \cdot 19,83 \cdot 27,0 \cdot 10^{6}-1304 \cdot 2000(375-675)-$

$$
489,0 \cdot 260(375-75)=1640 \cdot 10^{6} \mathrm{Nmm},
$$

where the first moment of the area $\Delta A_{c}$ about the midheight of the section:

$$
\Delta S_{c}=90000 \cdot 300=27,0 \cdot 10^{6} \mathrm{~mm}^{3} .
$$

2) The calculations based on the stress-strain diagram with inclined top branch.

The coefficients of Eq (13) are:

$$
\begin{aligned}
& B=\left[f_{p d}-\left(f_{p d}-\sigma_{p 1 m}\right) \frac{\bar{E}_{p}}{E_{p}}-\bar{\sigma}_{p c, u}\right] A_{p 1}+ \\
& \sum_{j=2}^{3}\left(\sigma_{p j m}-\sigma_{p c, u}\right) A_{p j}-\eta f_{c d} \Delta A_{c}= \\
& {\left[1304-(1304-1000) \frac{8290}{195000}-29,01\right] 2000+} \\
& (1000-682,5) 400+(1000-682,5) 260- \\
& 1 \cdot 19,83 \cdot 90000=949,0 \cdot 10^{3} \mathrm{~N}, \\
& C=\bar{\sigma}_{p c, u} A_{p 1} d_{p 1}+\sum_{j=2}^{3} \sigma_{p c, u} A_{p j} d_{p j}= \\
& 29,01 \cdot 2000 \cdot 675+682,5 \cdot 400 \cdot 375+ \\
& 682,5 \cdot 260 \cdot 75=154,8 \cdot 10^{6} \mathrm{Nmm} .
\end{aligned}
$$

The height of compression zone: $x=\frac{949,0 \cdot 10^{3}+\sqrt{\left(949,0 \cdot 10^{3}\right)^{2}+4 \cdot 4759 \cdot 154,8 \cdot 10^{6}}}{2 \cdot 4759}=$

$306 \mathrm{~mm}$

The steel stresses:

$$
\sigma_{p 1}=f_{p d}-\left(f_{p d}-\sigma_{p 1 m}\right) \frac{\bar{E}_{p}}{E_{p}}+\bar{\sigma}_{p c, u}\left(\frac{d_{p 1}}{x}-1\right)=
$$$$
1304-(1304-1000) \frac{8290}{195000}+29,01\left(\frac{675}{306}-1\right)=
$$

$1326 \mathrm{~N} / \mathrm{mm}^{2}<\frac{f_{p k}}{\gamma_{s}}=1539 \mathrm{~N} / \mathrm{mm}^{2}$,

$$
\sigma_{p 2}=\sigma_{p 2 m}+\sigma_{p c, u}\left(\frac{d_{p 2}}{x}-1\right)=1000+682,5\left(\frac{375}{306}-1\right)=
$$

$1154 \mathrm{~N} / \mathrm{mm}^{2}<f_{p d}=1304 \mathrm{~N} / \mathrm{mm}^{2}$,

$$
\sigma_{p 3}=\sigma_{p 3 m}+\sigma_{p c, u}\left(\frac{d_{p 3}}{x}-1\right)=1000+682,5\left(\frac{75}{306}-1\right)=
$$

$484,9 \mathrm{~N} / \mathrm{mm}^{2}$.

The ultimate moment resistance of section:

$$
\begin{gathered}
M_{R d}=1 \cdot 19,83 \cdot 300 \cdot 0,8 \cdot 306(375-0,5 \cdot 0,8 \cdot 306)+ \\
1 \cdot 19,83 \cdot 27,0 \cdot 10^{6}-1326 \cdot 2000(375-675)- \\
484,9 \cdot 260(375-75)=1660 \cdot 10^{6} \mathrm{Nmm} .
\end{gathered}
$$

\section{Conclusions}

The flexural strength analysis of reinforced and prestressed concrete members is performed. A new practical method for calculating the height of the compression zone at ultimate moment resistance is presented. The method is applicable to symmetrical cross-sections with any number of the reinforcing and prestressing steel layers and is valid for both normal and high-strength concretes. The stresses in the concrete are derived from the rectangular stress distribution and the stresses in the steel from stress-strain diagrams with a horizontal or an inclined top branch. The proposed method is illustrated by a numerical example.

The essential points of the present method compared with other practical methods are:

- there is no need to concentrate reinforcement on one level;

- prestressing steel can be with different levels of prestressing;

- the method is valid for high-strength concrete, too. 


\section{References}

1. BARAN, E.; SCHULTZ, A. E.; FRENCH, C. E. Analysis of the flexural strength of prestressed concrete flanged sections. Journal of the Prestressed Concrete Institute, Jan-Febr 2005, Vol 50, No 1, p. 74-93.

2. SEGUIRANT, S. J.; BRICE, R.; KHALEGHI, B. Flexural strength of reinforced and prestressed concrete T-beams. Journal of the Prestressed Concrete Institute, Jan-Febr 2005, Vol 50, No 1, p. 44-73.

3. SKRINAR, M. Flexural analysis of reinforced concrete $T$ cross sections according to EC2 standard for strains $\mathrm{e}_{\mathrm{c} 2}$ smaller than 2,0 \%. In Proc in Applied Mathematics and Mechanics, March 2002, Vol 1, No 1, p. 175-176.

4. GRÜNBERG, J.; KLAUS, M. Diagramme für die gezielte Querschnittsbemessung bei Interaktion von Längskraft und Biegemoment nach DIN 1045-1. Beton- und Stahlbetonbau, Aug 2001, Vol 96, No 8, p. 539-547.

5. GRÜNBERG, J.; KOSMAHL, M. Bemessungsdiagramme für die Biegetragfähigkeit von Plattenbalkenquerschnitten nach
DIN 1045-1. Beton- und Stahlbetonbau, Febr 2003, Vol 98, No 2, p. 59-65.

6. SALMONS, J. R.; MCLAUGHLIN, D. G. Design charts for proportioning rectangular prestressed concrete columns. Journal of the Prestressed Concrete Institute, Jan-Febr 1982, Vol 27, No 1, p. 120-143.

7. European Standard. EN 1992-1-1. Eurocode 2: Design of concrete structures. Part 1.1: General rules and rules for buildings. Dec 2004. 225 p.

8. CARREIRA, D. J. General solution of flexural strength of bonded prestressed concrete sections. Journal of the Prestressed Concrete Institute, May-June 2006, Vol 51, No 3, p. 2-17.

9. GHALLAB, A.; BEEBY, A. W. Ultimate strength of externally strengthened prestressed beams. Structures \& Buildings, Nov 2002, Vol 152, No 4, p. 395-406.

10. NAAMAN, A. E. Unified bending strength design of concrete members: AASHTO LRFD Code. Journal of Structural Engineering, June 1995, Vol 121, No 6, p. 964-970.

\section{PAPRASTU IR IŠ ANKSTO IৃTEMPTU GELŽBETONINIŲ ELEMENTU ATSPARUMO LENKIMUI SKAIČIAVIMO METODAS}

\section{T. Pedak, V. Otsmaa}

Santrauka

Straipsnyje nagrinėjamas paprastų ir iš anksto itemptų gelžbetoninių elementų atsparumas lenkimui, kai skerspjūvis vienodai apkrautas simetrijos ašies atžvilgiu. Pasiūlytas naujas gniuždomosios zonos aukščio skaičiavimo metodas. Jis tinka paprastiems ir didelio stiprumo betonams, kai ịtempių pasiskirstymas skerspjūvyje ịvairus. Pasiūlytasis metodas remiasi Eurocode 2 išdèstytomis prielaidomis, supaprastinimais ir medžiagų charakteristikomis. Pasiūlytos skaičiavimo formulès stačiakampiam įtempių pasiskirstymui nustatyti gniuždomoje betono zonoje ir plieno tempimo įtempių diagramoms braižyti. Pateiktas praktinis metodo taikymo pavyzdys.

Reikšminiai žodžiai: skaičiavimo metodas, atsparumas lenkimui, paprastas ir iš anksto įtemptas gelžbetonis, betonas, simetriškas skerspjūvis, išlinkimo ašis, gniuždomosios zonos aukštis.

Tiit PEDAK. MSc (CE), PhD student at the Dept of structural design of Tallinn university of technology. Field of research: reinforced and prestressed concrete structures.

Vello OTSMAA. PhD, Assoc Prof at the Dept of structural design of Tallinn university of technology. Field of research: theory of reinforced and prestressed concrete, design methods of concrete structures. 